\title{
The Cultivation Model of Higher Vocational Computer Professional Field Work Research
}

\author{
Jin $\mathrm{Wu}^{1, \mathrm{a}}$, Xiaojuan Sun ${ }^{2, \mathrm{~b}}$ \\ ${ }^{1}$ Department of Information Engineering, Liaoning Forestry Vocational and Technical College \\ Shenyang, P. R. China \\ ${ }^{2}$ Department of Information Engineering, Liaoning Forestry Vocational and Technical College \\ Shenyang, P. R. China \\ aemail:Wuzhixuan_2010@163.com, bemail:Sunxiaojuan8@163.com
}

Keywords: Field work; management; evaluation

\begin{abstract}
Encourage students to theory and practice of organic combination, it can complement the enterprise technical force, solve the problem of enterprise talent shortages. Field work is an important part of the personnel training. strict management, evaluation and assessment must be conducted.
\end{abstract}

Higher vocational education is a kind of education form of improving national quality. At present, the status of higher vocational education in the higher education is increasingly important. Education is the foundation of the people's livelihood, employment is vital to people's livelihood, this is mainly reflected in the higher vocational education's contribution to employment ability. Field work is a kind of important form of teaching in higher vocational education, higher vocational colleges is to speed up to promote the school and enterprise cooperation, an important form of practical talent cultivation, is an important practice link of higher vocational college students' comprehensive skills, in the higher vocational teaching plays a very important role. The traditional pattern of higher vocational education has the disadvantages of large, outstanding performance in the students' practical training is insufficient, teaching model and the field work to address the shortcomings. Through school and enterprise cooperation, the practice of the field work, I more profoundly realize: practice, field work personnel training mode of higher vocational colleges, the college students, all has the extremely positive significance to the enterprise, as long as perseverance, constantly improve, to achieve mutual benefit and win more good results.

To cultivate the students' social adaptability, the important way of improve students' practical ability and practice ability, creative ability, employment ability and entrepreneurial ability , is go to society and go to work, to realize "zero distance" employment practice training, strengthen the management of field work students effective implementation plan and evaluation measures.

Field work is the "decision on vigorously develop vocational education by the state council" (guo fa [2009] no. 36) in the " $2+1$ " education mode, namely the school study two years (for one year to learn basic stuff, one year to learn skills), in the third year go to the designated enterprise specialized in corresponding counterpart, paid internship for 12 months, and then arranged employment by school[1-3]. This kind of curriculum and teaching mode to adhere to the theory with practice, to practice, using the brain and hand, teach, learn, do one, improve the comprehensive vocational ability of vocational school graduates.

Assessment of management is to cultivate the students' social adaptability, improve students' practical ability and practice ability, creative ability, employment ability and entrepreneurial ability the important way, from school to society, to work, to achieve "zero distance" employment practice training, strengthen the management of students' field work, to ensure that students during field 
work discipline, safety civilization, the successful completion of the internship tasks, formulates this implementation and assessment measures. The students participate in field work, jointly by schools and field work unit to examination and assessment grades.

\section{Of both the field work condition of students in higher vocational colleges}

Exploration of higher vocational computer application technology professional student field work management process monitoring and evaluation system of research in domestic higher vocational education is a new research field. Field work is an effective implementation of workintegrated learning personnel training mode in higher vocational colleges, the most important ways that the field work students education management is the guarantee of improving the quality of higher vocational talents training, such as the Beijing colleges and universities, status, role and characteristics of higher vocational education personnel training mode research, but mainly issue is the study of talent training mode in higher vocational colleges. And ignore the field work is an important part of the personnel training, strict management, evaluation and assessment must be conducted.

\section{The meaning of the field work in higher vocational colleges students}

Field work is in higher vocational colleges and universities take full advantage of social education resources the effective ways to do a good job in higher vocational education. Student field work is conducive to further promote university-enterprise cooperation and work-integrated learning personnel training mode reform; Field work is conducive to further enhance the process of teaching students the practicality, openness and the professional pertinence; Field work is good for students to better adhere to the "service for the purpose, employment as orientation" of vocational education school policy, promote the recruitment and employment. Field work, therefore, make enterprise has a group of high quality, high skills, relatively stable workers, can complement technology, solve the problem of enterprise talent shortages, at the same time, also can enrich the enterprise culture, improve the economic benefit[4].

\section{This exploration, school and enterprise cooperation field work the necessity of training mode}

\section{A. Accelerate the pace of vocational colleges students' employment}

Vocational colleges students at the last school year to the enterprise to participate in field work, to really apply theoretical knowledge to practical work, is conducive to a more objective understanding society, forming a more pragmatic view and are greatly. Through field work, students can master more employment information, and realize effective link of individual employment and enterprise needs, to enhance their employment competition ability, laid the foundation for employment after graduation, so as to improve the higher vocational students' employment rate. At the same time, because practice field work can help students to gain valuable work experience, can fully improve the students' actual ability to work, so that the graduates can quickly achieve the role change from student to enterprise staff, to let them quickly after graduation by unit of choose and employ persons employed[4-5].

\section{B. Improve the higher vocational students' comprehensive quality}

Practice has proved that through the field work, the higher vocational students' practical ability and social adaptation ability and professional quality can be improved. At present, many higher vocational education colleges have their own on-campus and off-campus training base, the students in these training bases for exercise, can cultivate the practical ability to a certain extent, but because of constantly improve, to cultivate college students' practice ability training base has been difficult to meet the requirements of training higher vocational students' practical ability to improve, through field work and students, can really participate in the enterprise actual work tasks and work, through practice, students will become more assertive in skills, thus strengthening the ability of independent of production and would be easier to work, to work in practice can constantly discover problems, analyze and solve problems. 
C. Improve the higher vocational students' learning enthusiasm

Tired in today's professional class is very common in colleges and universities students, vocational colleges in teaching after the implementation of field work, can fully arouse the enthusiasm of students learning. Students through field work in enterprises, not only can increase students' interest in learning, and can let students get some labor income in the field work, greatly increase the attraction of the higher vocational students to study.

D. Shorten the enterprise new employees training cycle

Enterprises to improve their production efficiency, must need to develop new technology and high skills of practical talents. Talents often takes time and effort, field work is common higher vocational school and enterprise to develop talent, this method not only can help enterprises save a lot of training resources, and can shorten the training time.

\section{The higher vocational college computer professional some drawbacks during the field work personnel training mode}

A. Student

Computer professional students internship scattered, poor stability, education management is difficult.

The student ideological understanding fuzzy, bear ability is poor, can not correctly treat the frustrations at work.

\section{B. Internship units}

The lack of a large number of relatively stable and can satisfy the requirement of field work offcampus practice base. Computer professional students internship mismatch, individual students contact the internship with the professional training goal, don't play a role of field work.

Part of the enterprise to the field work in higher vocational colleges students lack the sense of identity and acceptance of field work of higher vocational students' enthusiasm is not high.

\section{Schools}

Part of the teachers and teaching management personnel did not change teaching ideas, to field work teaching seriously insufficient, inadequate inputs.

The lack of effective process monitoring and evaluation system.

Lack of controlable field work long-term management mechanism to ensure the quality of internship.

\section{The higher vocational computer professional students training mode management of field work during the appraisal and evaluation}

Field work stage management, the evaluation and assessment is different from in the school of management and evaluation, assessment of the management of evaluation main body should be between both sides, in order to achieve through the field work to improve students' skills and comprehensive quality.

\section{A. Computer professional students management}

Computer professional students management work is the necessary condition to achieve the practice teaching, is an important means to improve students' professional quality, students shall, in accordance with the industry enterprise standard management, causes the student to develop orderly and in strict accordance with procedures and labor safety and occupational character. In the enterprise field work students should first clear their dual role, internship is not only the students, the school and internship unit worker, each student is to the worker's identity to internship internship units. School should undertake to the student into the company, therefore, education, students are required to obey the company rules, obey the responsibility, put an end to relieve guard, field and absences are a phenomenon. At the same time, also want to know the basic rule of enterprise, the unit operation, principle, etc., familiar with internship unit's internal management, strengthen the ability to adapt, lay a solid foundation for future employment. 


\section{B. Quality monitoring and assessment}

To examine the strengthening process management, and more time. Strengthening process inspection, require companies to guide teachers to practice student discipline, practice, attitude and practice effects such as truthfully as record, and a quantitative assessment. Set up evaluation index system, strictly the field work of the whole process of supervision, the objective to identify the field work.

Make joint between colleges students field work management system and the text field work process management assignments, including: the internship agreement between colleges, practice discipline, inter alia, internship internship and job log monitoring manual, practice guidance teachers' responsibilities, practice guidance teachers' work log, enterprise field work appraisal opinion, field work course transcripts, enterprise certificate of work experience and so on series of text, and applied to the student field work entire process. Implement field work process management, at the same time, develop "as the center" the other short-term measures for the management of field work. During the period of training, wuxi's sentiment of students, the spirit of unity and cooperation, law-abiding habits and professional quality "nurturance education", for the future and development laid a solid foundation to be going to work[5].

\section{Conclusion}

Higher vocational computer professional students through strict evaluation in field work, in order to strengthen the management of student talent training pattern of field work during the appraisal and evaluation, to make the students pay more attention to field work of teaching learning, constantly improve their professional skills and comprehensive quality, and contribute to the formation of the field work of teaching quality, to improve employment competitiveness.

\section{References}

[1] H.P Hong. "Based on the Field Work School-enterprise Cooperation in Higher Vocational Talents Training Mode to Explore”, Journal of anshun university [J], 2010 12(10) 55-57.

[2] Office of Academic Affairs. Guidelines for the preparation of Course examination program. Shenyang: Liaoning Forestry Vocational and Technical College[J], 2012(4) 5-6.

[3] X.J Wang. "Study based on the Integrated curriculum assessment program”, Practice and exploration[J], 2011(11)86-88.

[4] Y.H Hu, N. Zhang. "Study on network in NC professional post teaching practice teaching", Technological Innovation Herald[J], April 2010 18(4)98-100.

[5] S.C Liu, J. Yuan, S.J Si."Combining learning with working" Explore on students’ ideological work during post practice[J], 2010(7)108-120. 